\title{
KEMATANGAN KARIR MENGGUNAKAN TES MI SEBAGAI PENDUKUNG TES SDS PADA MAHASISWA UNIVERSITAS PANCASAKTI TEGAL
}

\author{
Hastin Budisiwi \\ Prodi Bimbingan dan Konseling, FKIP, Universitas Pancasakti Tegal, hastinbudisiwi@gmail.com \\ M.Arif Budiman S. \\ Prodi Bimbingan dan Konseling, FKIP, Universitas Pancasakti Tegal, arifups88@ gmail.com
}

\begin{abstract}
Abstrak
Tujuan penelitian untuk memperoleh informasi dengan menjelaskan perencanaan karir melalui uji hubungan MI (Multiple Intellegence) dan menguji SDS (Self Directed Search) sebagai kebutuhan siswa dalam memilih perencanaan karir. Pendekatan penelitian ini menggunakan deskriptif kualitatif. Data yang diperoleh adalah hasil tes MI (Multiple Intelligence) dan SDS (Self Directed Search) mahasiswa semester VII program studi bimbingan dan konseling. Objek penelitian adalah hubungan antara MI dan SDS hasil tes. Pengetahuan tentang karir menuntut siswa yang berada di semester ketujuh untuk mendapatkan pekerjaan yang layak sesuai dengan kompetensi mereka. Dengan mengetahui hasil tes MI dan uji SDS mahasiswa diharapkan dapat menentukan keputusan karir sebagai rencana awal dari pengembangan karir. Populasi yang diteliti adalah mahasiswa semester VII program studi bimbingan dan konseling.
\end{abstract}

Kata kunci: Karir, MI, SDS, Mahasiswa

\begin{abstract}
The aim of study to obtain information by describing career planning through the relationship test MI (Multiple Intellegence) and test SDS (Dominance, Inducement, Submissive, Compliance) as the needs of students in choosing career planning. This research approach use descriptive qualitative. Data obtained are the results of the MI and SDS test students VII semester guidance and counseling program. The object of research is the relationship between MI and SD test results. Knowledge of a career requires students who are in the seventh semester in order to get a decent job in accordance with their competence. By knowing the results of MI test and test of SDS expected student can determine career decision as plan early from career development. The population studied is a VII semester student guidance and counseling program with. Results obtained from charging kuisoner distribution is a significant relationship relationship between MI and SDS test results based on the suitability of job choice.
\end{abstract}

Keywords: Career, MI, SDS, Student

\section{PENDAHULUAN}

Pemilihan karir merupakan hal yang harus diputuskan dengan pertimbangan yang tepat dan juga dilakukan guna kelanjutan aktifitas kehidupan dengan keyakinan bahwa pilihan yang diambil adalah pilihan yang terbaik. Menurut Hastin (2013) kematangan karir memiliki pengertian sebagai proses yang menimbulkan tingkah laku yang baru sebagai akibat dari pertumbuhan dan perkembangan. Pertumbuhan mendasari perkembangan, sedangkan perkembangan berhubungan dengan fungsi-fungsi tubuh dan jiwa sehingga terjadi diferensiasi.Dengan demikian kesiapan individu dalam membuat keputusan karir yang tepat dapat dikatakan sebagai kematangan karir. Menurut Riyadi (2006) kematangan karir ditandai oleh enam hal yaitu : (1) keterlibatan dalam aktivitas perencanaan karir; (2) keinginan untuk mendapatkan informasi tentang karirdan menggali informasi karir; (3) memiliki pengetahuan tentang membuat keputusan karir yang tepat; (4) memiliki pengetahuan mengenai informasi pekerjaan dan dunia kerja; (5) menekuni pekerjaan yang disukai (6) realistis dalam membuat keputusan dalam memilih karir. Berkaitan dengan hal tersebut maka dalam kematangan karir dibutuhkan suatu usaha untuk mengeksplor informasi, pengetahuan serta dapat mendalami karir yang akan menjadi pilihan.

Tantangan yang harus dihadapi oleh mahasiswa bimbingan dan konseling semester tujuh Universitas Pancasakti Tegal tidak hanya menyelesaikan skripsi sebagai tugas akhir akan tetapi mahasiswa harus mencari informasi dan memperoleh pekerjaan yang layak sesuai dengan minat yang dicita-citakan. Lulusan mahasiswa jurusan bimbingan dan konseling tidak hanya dapat menjadi guru dan konselor disekolah akan tetapi juga 
dapat bekerja di Bank, LSM, LP, BNN, Kantor pemerintah, Panti Rehabilitasi, KPAI, HRD, dosen, dan wiraswasta dengan mendirikan lembaga konseling atau jasa tes psikolgi. Dengan pemilihan pekerjaan yang sesuai dengan kompetensinya diharapkan mahasiswa dapat mengembangkan karir.

Berdasarkan pengamatan yang dilakukan peneliti, $60 \%$ mahasiswa bimbingan dan konseling semester VII Universitas Pancasakiti Tegal (UPS) belum memiliki kematangan karir. Keadaan tersebut dibuktikan saat beberapa mahasiswa ditanya tentang pemilihan pekerjaan setelah lulus kuliah yang akan menjadi bagian dari masa depan dan perkembangkan karir. Sebagian mahasiswa masih ragu ragu dalam mempertimbangan keputusan pilihan pekerjaan yang diharapkan sesuai dengan kompetensi. Keraguan yang dimaksud mahasiswa didasari oleh beberapa sebab antara lain, dari segi sikap, bakat minat, dan kompetensi. Dari segi sikap mahasiswa belum memiliki perencanaan karir yang matang dengan demikian bisa dipastikan bahwa mahasiswa belum ikut terlibat dalam aktivitas karir, hal tersebut dapat berdampak dengan minimnya informasi peluang karir yang akan menjadi tujuan pemilihan karir. Dari penjelasan diatas sangat wajat jika mahasiswa terdapat keraguan yang tidak berdasar. Dan dari Segi bakat dan minat mahasiswa belum mengetahui kemampuan dan pengetahuan tetntang potensi yang dimiliki. Sehingga mahasiswa masih belum dapat memaksimalkan potensi yang ada pada dirinya. Sedangkan dari segi kompetensi yaitu minimnya pengetahuan dalam menyusun perkembangan karir serta kurangnya mahasiswa dalam mendalami keahlian sesuai dengan kompetensi. Sehingga arah pemilihan pekerjaan yang sesuai dengan latar belakang dan tujuan mereka belum jelas akan dibawa kemana.

Terjadinya fenomena rendahnya keyakinan mahasiswa dalam pemilihan karir dapat berdapak pada perkembangan karir mahasiswa sehingga kesiapan dalam membuat keputusan yang tepat untuk masa depannya. Dengan demikian perlu adanya strategi perencanaan karir dengan harapan mahasiswa mampu mengenali pola minat dalam pemilihan pekerjaan tanpa keragu-raguan. Salah satu Alternatif yang tepat untuk menjawab tuntutan strategi perencanaan karir adalah mengunakan test MI sebagai penguat SDS dalam memantapkan pemilihan karir. Howard Gardner adalah tokoh psikologi yang sangat terkenal dalam lingkungan pendidikan karena teori yang diciptakan tentang multiple intelegences. Menurut Wijk Charles H. Van, Fauri Marilize (2017) "Specifically, Gardner questioned the construct validity of $\mathrm{g}$, and suggested that the measures we used to test his theory were contaminated with verbal and logical demands. In this reply, we explain that the construct validity of $\mathrm{g}$ is well established, pointing out (a) that $\mathrm{g}$ is expressed in a wide variety of tasks (not all of which are "school-like" tasks), (b) that $\mathrm{g}$ predicts many important criterion variables (not only academic achievement), and (c) that $g$ has a well-established biological basis". Menurut Howard Gardner ada delapan karakteristik intelegensi yaitu intelegensi berbahasa/linguistik, intelegensi logismatematis, intelegensi visual-spasial, intelegensi kinestetis, intelegensi musikal, intelegensi naturalis, dan intelegensi interpersonal, serta intelegensi intrapersonal.

Howard Gardner (2003) membagi MI (multiple intelegence) dalam sembilan kecerdasan, yaitu:

1) Kecerdasan logik matematik merupakan kemampuan yang dimiliki seseorang dalam berhitung, mengukur, dan juga dapat mengoperasikan angka-angka.

2) Kecerdasan linguistik merupakan kemampuan berpikir dalam bentuk kata-kata (cerita) serta dapat menggunakan bahasa untuk mengekspresikan dan memaknai kata.

3) Kecerdasan musikal merupakan kemampuan dalam hal menghasilkan dan mengekspresikan ritme, nada dan bentukekspresi musik yang keseluruhannya melibatkan fungsi panca indra.

4) Kecerdasan spasial-visual merupakan kemampuan melihat dan mengamati gambar dengan cermat.

5) Kecerdasan bodily kinesthetic merupakan kemampuan belajar perilaku nyataberdasarkan pengalaman melaui praktek langsung.

6) Kecerdasan intrapersonal merupakan kemampuan membuat persepsi yang tepat mengenai diri sendiri dan menggunakan kemampuan tersebut dalam membantu orang lain.

7) Kecerdasan interpersonal merupakan kemampuan dalam memahami orang lain sehingga dapat berinteraksi dengan orang lain secara efektif.

8) Kecerdasan naturalis merupakan kemampuan memahami kondisi dan situasi alam beserta lingkungan.

9) Kecerdasan eksistensialis merupakan kemampuan dalam memaknai dan menunjukkan peranannya dalam kehidupan.

Dari uraian diatas dapat dipahami bahwa setiap manusia memiliki berbagai macam kecerdasan. Menurut Ardimen Kecerdasan dalam hal ini dapat dibagi menjadi dua dimensi, yaitu; kecerdasan potensial dan kecerdasan aktual atau nyata. Kecerdasan potensial adalah kemampuan dasar yang bersifat potensi pribadi yang dimiliki oleh seseorang atau sering disebut dengan bakat (bibit unggul yang ada dalam diri). Di sisi lain yang dimaksud dengan kecerdasan aktual atau nyata adalah kemampuan seseorang yang telah berkembang melalui berbagai latihan dan kesempatan dalam kehidupan sehingga mampu menyelesaikan 
persoalan tertentu dalam kehidupannya. Dengan demikian untuk mengeksplorasi dan mendalami spesifikasi kecerdasan mahasiswa perlu menggunankan alat test.Dengan test ini diharapkan dapat mengenali dan memahami serta mengembangkan kecerdasanya yang menjadi unggulan khas masing-masing individu.

SDS (Self Directed Search) merupakan sebuah tes yang didasarkan pada teori Holland yang di dalamnya terdapat penjelasan mengenai kombinasi kepribadian individu berdasarkan 6 tipe kepribadian yang disebut RIASEC Realistis, Investigasi, Artistik, Social , Enterprising, Konvensional. Menurut Tigor (2013) Berikut penjabaran model orientasi Holland:

Tipe Realistik: menyukai pekerjaan yang realistik seperti mengutak-atik mesin mobil, pesawat terbang, penyurvei, petani, ahli listrik. Memiliki kemampuan mekanik namun kadang kurang memiliki kemampuan sosial. Karakteristik individu dengan tipe realistik adalah sebagai berikut: asosial, dapat menyesuaikan diri, terus terang, apa adanya, keras kepala, tidak fleksibel, materialistik, praktis, hemat, tidak memiliki ide, sulit terlibat dengan sesuatu.

Tipe Investigatif: menyukai pekerjaan seperti biolog, ahli kimia, fisikawan, antropolog, geolog dan teknolog medis. Memiliki kemampuan matematis dan ilmiah namun sering kurang punya kemampuan kepemimpinan. Karakteristiknya individu dengan tipe investigatif meliputi: analitis, berhati-hati, kritis, rasa ingin tahu yang besar, independen, intelektual, pesimis, tepat, rasional, antisipatif, menarik diri, tidak populer dan tidak berprasangka.

Tipe Artistik: menyukai pekerjaan seperti komposer, musisi, sutradara, penulis, dekorator interior, artis. Memiliki kemampuan artistik seperti menulis, bermusik atau bentukseni lainnya, namun kurang punya kemampuan administrasi yang baik. Karakteristik individu dengan tipe artistikadalah: rumit, tidak teratur, emosional, idealis, imajinatif,ekspresif, tidak praktis, impulsif, independen, terbuka, dan sensitif.

Tipe Sosial: menyukai pekerjaan seperti guru, pekerja rohani, konselor, pekerja sosial, psikiater/psikolog klinis, terapis, dokter, perawat. Memiliki keahlian dan talenta sosial yang tinggi, namun sering kurang punya kemampuan mekanikdan ilmiah. Karakteristik individu dengan tipe sosial meliputi: berpengaruh, kooperatif, empatik, ramah, murah hati, siap menolong, idealistik, baik hati, sabar, persuasif, bertanggung jawab, mudah bergaul, bijak, penuh pengertian, dan hangat.

Tipe Pengusaha: menyukai pekerjaan seperti sales, manajer, eksekutif bisnis, produser tivi, romotor olahraga, pialang saham, pekerja iklan. Memiliki kemampuan memimpin dan fasih erbicara namun sering kurang punya kemampuan ilmiah. Karakteristik individu dengan tipe pengusaha meliputi: ambisius, mudah sepakat, berjia petualang, mendominasi, tidak pernah merasa cukup, penuh semangat, ekstrovert, suka merayu, percaya diri, optimis, mudah bergaul, dan enak diajak berbicara.

Tipe Konvensional: menyukai pekerjaan yang konvensional seperti penjaga toko, stenografer, pustakawan, analis finansial, bankir, pengestimasi biaya, ahli pajak. Memiliki kemampuan matematis dan aritmetika namun sering kurang punya kemampuan artistik. Karakteristik individu dengan tipe konvensional meliputi: cermat, dapat menyesuaikan diri, penuh kesadaran, efisien, tidak fleksibel, pandai menahan diri, patuh, teratur, gigih, praktis, sopan, hemat dan tidak imajinatif.

Pada maing-masing tipe kepribadian juga memiliki spesifikasi pekerjaan yang sudah bisa diprediksikan antara lain: (1) Tipe Realistik, contoh pekerjaan individu dengan tipe orientasi ini adalah, operator mesin/radio, sopir truk, petani, penerbang, pengawas bangunan, ahli listrik, dan pekerjaan lain yang sejenis. (2) Tipe Investigatif, contoh pekerjaan individu dengan tipe orientasi ini adalah, ahli fisika, ahli biologi, kimia, antropologi, matematika, pekerjaan penelitian, dan pekerjaan lain yang sejenis.(3) Tipe Arsisitik,contoh pekerjaan individu dengan tipe orientasi ini adalah, ahli musik, ahli kartun, ahli drama, pencipta lagu, penyair, dan pekerjaan lain yang sejenis. (4) Tipe Sosial,contoh pekerjaan individu dengan tipe orientasi ini adalah, guru, pekerja sosial, konselor, misionari, psikolog klinik, terapis, dan pekerjaan lain yang sejenis. (5) Tipe Pengusaha, contoh pekerjaan individu dengan tipe orientasi ini adalah, pedagang, politikus, manajer pimpinan eksekutif perusahaan, perwakilan dagang, dan pekerjaan lain yang sejenis. (6) Tipe Konvensional, contoh pekerjaan individu dengan tipe orientasi ini adalah, kasir, statistika, pemegang buku, pegawai arsip, pegawai bank, dan pekerjaan lain yang sejenis.

Menurut Wijk Charles H. Van, Fauri Marilize (2017)" In contested labour markets in developing countries, vocational interest in-ventories could potentially match applicants to speciality occupation".. Dapat disimpulkan bahwa kesesuaian minat vokasional dalam pencarian lapangan pekerjaan dapat mencocokan pelamar dengan pekerjaan dibidang yang khusus.

Sebenarnya banyak hal yang bisa dilakukan oleh mahasiswa ketika mereka mengetahui kecerdasan yang dimilikinya sebagai usaha mendukung kemampuan dalam pengembangan karir. Salah satu alternatif yang mampu menjawab tuntutan kondisi tersebut adalah dengan mempersiapkan keputusan karir. Keputusan karir yang harus berdasarkan dengan alat test SDS dan MI untuk dapat mendalami pekerjaan yang disukai. Berdasarkan kompetensi yang dimiliki, kemampuan dalam pilihan 
pekerjaan bisa dilihat melaui test MI sebagai penguat SDS.

\section{METODE}

Penelitian ini menggunakan metode deskriptif kualitatif.Menurut Sugiyono (2009) metode deskriptif adalah metode yang digunakan untuk menganalisis hasil penelitian tetapi bukan untuk membuat kesimpulan yang lebih luas. Metode ini dipilih karena dapat mencari fakta dengan akurat dan interpretasi yang tepat. Penggunaan metode deskriptif kualitatifdilakukan peneliti untuk memberikan gambaran hasil test MI dan SDS pada hasil angket kuisioner mahasiswa. Metode pengumpulan data melalui wawancara, angket dan dokumentasi. Penelitian dilakukan di Kampus Universitas Pancasakti Tegal pada mahasiswa bimbingan konseling pada tanggal 8 sampai 29 Desember 2017. Subyek penelitian adalah mahasiswa bimbingan konseling semester VII.

\section{HASIL DAN PEMBAHASAN}

Hasil test didapatkan dari hasil pengisian angket kuisioner test MI dan SDS adalah :

Hasil Test MI S1 memiliki kecerdasan logika, yang dicirikan berpikir secara logis dan dapat menjelaskan setiap hal secara logis, menanggapi sesuatu berdasarkan logika atau tidak, biasanya tertarik dengan hal-hal yang berbau teknologi. Karir yang cocok untuk S1 adalah ilmuwan, insinyur, ahli komputer, akuntan, peneliti, analis keuangan.

Hasil Tets SDS S1 : Realistic : 20 Investigative : 25 Artistic : 14 Social : 32 Enterprising : 18 Conventional : 26, nilai yang tertinggi dari hasil test tersebut adalah "Social" Tipe model ini memiliki kecenderungan untuk memilih lapangan pekerjaan yang bersifat membantu orang lain. Ciri-ciri dari tipe model ini adalah pandai bergaul dan berbicara, bersifat responsif, bertanggung jawab, kemanusiaan, bersifat religius membutuhkan perhatian, memiliki kecakapan verbal, hubungan antarpribadi, kegiatan-kegiatan rapi dan teratur, menjauhkan bentuk pemecahan masalah secara intelektual, lebih berorientasi pada perasaan. Karir yang cocok antara lain adalah guru, pekerja sosial, konselor, psikolog klinis, terapis dll.

Hasil Test MI S2 memiliki kecerdasan bahasa yang dicirikan suka dengan permainan bahasa (teka-teki silang,scrabble,dll), pandai dan menyenangi debat/diskusi, pandai dan cepat mempelajari bahasa asing. Karir yang cocok untuk SI adalah guru, konsultan media, presenter TV/ Radio.

Hasil tets SDS S2 : Realistic : 11 Investigative : 19 Artistic : 26 Social : 38 Enterprising : 30 Conventional : 25, Tipe model ini memiliki kecenderungan untuk memilih lapangan pekerjaan yang bersifat membantu orang lain. Ciri-ciri dari tipe model ini adalah pandai bergaul dan berbicara, bersifat responsif, bertanggung jawab, kemanusiaan, bersifat religiusm membutuhkan perhatian, memiliki kecakapan verbal, hubungan antarpribadi, kegiatan-kegiatan rapi dan teratur, menjauhkan bentuk pemecahan masalah secara intelektual, lebih berorientasi pada perasaan. Contoh pekerjaan orang dengan model orientasi ini adalah, guru, pekerja sosial, konselor, misionari, psikolog klinik, terapis, dan pekerjaan lain yang sejenis.

Hasil Test MI S3 memiliki kecerdasan pribadi yang dicirikan mandiri, lebih suka menyendiri, lebih suka punya ruangan kerja sendiri. Karir yang cocok untuk S3 adalah penulis, penasihat, psikolog, psikiater, peneliti.

Hasil test SDS S3 : Realistic : 3 Investigative : 4 Artistic : 8 Social : 12 Enterprising : 7 Conventional : 4, Tipe model ini memiliki kecenderungan untuk memilih lapangan pekerjaan yang bersifat membantu orang lain. Ciri-ciri dari tipe model ini adalah pandai bergaul dan berbicara, bersifat responsif, bertanggung jawab, kemanusiaan, bersifat religiusm membutuhkan perhatian, memiliki kecakapan verbal, hubungan antarpribadi, kegiatan-kegiatan rapi dan teratur, menjauhkan bentuk pemecahan masalah secara intelektual, lebih berorientasi pada perasaan. Contoh pekerjaan yang cocok guru, pekerja sosial, konselor, misionari, psikolog klinik, terapis.

Hasil Test MI S4 kecerdasan pribadi, yang dicirikan madiri, lebih suka menyendiri, lebih suka punya ruangan sendiri dan suka mengikuti pelatihan pengembangan diri. Karir yang cocok untuk S4 adalah penulis, penasihat, psikolog, psikiater dan peneliti.

Hasil test SDS S4: Realistic : 4 Investigative : 4 Artistic : 8 Social : 10 Enterprising : 5 Conventional : 3, Tipe model ini memiliki kecenderungan untuk memilih lapangan pekerjaan yang bersifat membantu orang lain. Ciri-ciri dari tipe model ini adalah pandai bergaul dan berbicara, bersifat responsif, bertanggung jawab, kemanusiaan, bersifat religius membutuhkan perhatian, memiliki kecakapan verbal, hubungan antarpribadi, kegiatan-kegiatan rapi dan teratur, menjauhkan bentuk pemecahan masalah secara intelektual, lebih berorientasi pada perasaan. Contoh pekerjaan orang dengan model orientasi ini adalah, guru, pekerja sosial, konselor, misionari, psikolog klinik, terapis, dan pekerjaan lain yang sejenis.

Hasil test MI S5 kecerdasan sosial, yang dicirikan ramah dan banyak senyum, mempunyai banyak teman dan relasi, rajin menjalin relasi baru dengan orang, banyak mempunyai teman dekat. Karir yang cocok untuk S5 
adalah politikus, guru, mediator, tenaga penjualan atau pemasaran.

Hasil Test SDS S5 Realistic : 8 Investigative : 6 Artistic : 32 Social : 35 Enterprising : 33 Conventional : 18. Tipe model sosial ini memiliki kecenderungan untuk memilih lapangan pekerjaan yang bersifat membantu orang lain. Ciri-ciri dari tipe model ini adalah pandai bergaul dan berbicara, bersifat responsif, bertanggung jawab, kemanusiaan, bersifat religiusm membutuhkan perhatian, memiliki kecakapan verbal, hubungan antarpribadi, kegiatan-kegiatan rapi dan teratur, menjauhkan bentuk pemecahan masalah secara intelektual, lebih berorientasi pada perasaan. Contoh pekerjaan orang dengan model orientasi ini adalah, guru, pekerja sosial, konselor, misionari, psikolog klinik, terapis, dan pekerjaan lain yang sejenis.

Hasil Test MI S6 kecerdasan sosial, yang dicirikan ramah dan banyak senyum, mempunyai banyak teman dan relasi, rajin menjalin relasi baru dengan orang lain. Karir yang cocok untuk S6 adalah politikus, guru, mediator.

Hasil test SDS S6 Realistic : 4 Investigative : 15 Artistic : 11 Social : 11 Enterprising : 14 Conventional : 15. Tipe model ini memiliki kecenderungan untuk memilih pekerjaan yang bersifat akademik. Ciri-cirinya adalah memiliki kecenderungan untuk merenungkan daripada mengatasinya dalam memecahkan suatu masalah, berorientasi pada tugas, tidak sosial. Membutuhkan pemahaman, menyenangi tugas-tugas yang bersifat kabur, memiliki nilai-nilai dan sikap yang tidak konvensional dan kegiatan-kegiatanya bersifat intraseptif. Contoh pekerjaan orang dengan model orientasi ini adalah, ahli fisika, ahli biologi, kimia, antropologi, matematika, pekerjaan penelitian, dan pekerjaan lain yang sejenis.

Hasil test MI S7 kecerdasan logika yang dicirikan berpikir secara logika dan dapat menjelaskan setiap hal secara logis, menanggapi sesuatu berdasarkan logika atau tidak, biasanya tertarik dengan hal-hal yang berbau teknologi. Karir yang cocok untuk S7 adalah ahli komputer, peneliti, riset dan pengembangan, akuntan.

Hasil tets SDS S7 Realistic : 12 Investigative : 8 Artistic : 18 Social : 29 Enterprising : 20 Conventional : 21. Tipe model ini memiliki kecenderungan untuk memilih lapangan pekerjaan yang bersifat membantu orang lain. Ciri-ciri dari tipe model ini adalah pandai bergaul dan berbicara, bersifat responsif, bertanggung jawab, kemanusiaan, bersifat religiusm membutuhkan perhatian, memiliki kecakapan verbal, hubungan antarpribadi, kegiatan-kegiatan rapi dan teratur, menjauhkan bentuk pemecahan masalah secara intelektual, lebih berorientasi pada perasaan. Contoh pekerjaan orang dengan model orientasi ini adalah, guru, pekerja sosial, konselor, misionari, psikolog klinik, terapis, dan pekerjaan lain yang sejenis.

Hasil test MI S8 memiliki kecerdasan sosial yang dicirikan ramah dan banyak senyum, mempunyai banyak teman dan relasi, rajin menjalin relasi baru dengan orang lain. Karir yang cocok untuk S8 adalah guru, politikus, mediator dan humas.

Hasil tets SDS S8 Realistic : 3 Investigative : 15 Artistic : 19 Social : 31 Enterprising : 16 Conventional : 11. Tipe model ini memiliki kecenderungan untuk memilih lapangan pekerjaan yang bersifat membantu orang lain. Ciri-ciri dari tipe model ini adalah pandai bergaul dan berbicara, bersifat responsif, bertanggung jawab, kemanusiaan, bersifat religiusm membutuhkan perhatian, memiliki kecakapan verbal, hubungan antarpribadi, kegiatan-kegiatan rapi dan teratur, menjauhkan bentuk pemecahan masalah secara intelektual, lebih berorientasi pada perasaan. Contoh pekerjaan orang dengan model orientasi ini adalah, guru, pekerja sosial, konselor, misionari, psikolog klinik, terapis, dan pekerjaan lain yang sejenis.

Hasil test MI S9 memiliki kecerdasan sosial yang dicirikan Rajin menjalin relasi baru dengan orang lain, Banyak mempunyai teman dekat, menikmati kebersamaan dengan orang lain atau suatu kegiatan keramaian, mampu bekerja sama dengan orang lain. Karir yang cocok untuk S9 adalah politikus, guru dan mediator.

Hasil test SDS Hasil tets SDS S9 Realistic : 6 Investigative : 3 Artistic : 7 Social : 16 Enterprising : 5 Conventional : 6 . Tipe model ini memiliki kecenderungan untuk memilih lapangan pekerjaan yang bersifat membantu orang lain. Ciri-ciri dari tipe model ini adalah pandai bergaul dan berbicara, bersifat responsif, bertanggung jawab, kemanusiaan, bersifat religiusm membutuhkan perhatian, memiliki kecakapan verbal, hubungan antarpribadi, kegiatan-kegiatan rapi dan teratur, menjauhkan bentuk pemecahan masalah secara intelektual, lebih berorientasi pada perasaan. Contoh pekerjaan orang dengan model orientasi ini adalah, guru, pekerja sosial, konselor, misionari, psikolog klinik, terapis, dan pekerjaan lain yang sejenis.

Hasil test MI S10 memiliki kecerdasan sosial memiliki ciri ciri ramah dan banyak senyum, mempunyai banyak teman dan relasi, rajin menjalin relasi baru dengan orang lain, banyak mempunyai teman dekat. Karir yang cocok untuk S10 adalah guru, polititikus mediator.

Hasil tets SDS S10 adalah Realistic : 9 Investigative : 9 Artistic : 17 Social : 25 Enterprising : 21 Conventional : 16. Tipe model ini memiliki kecenderungan untuk memilih lapangan pekerjaan yang bersifat membantu orang lain. Ciri-ciri dari tipe model ini adalah pandai bergaul dan berbicara, bersifat responsif, bertanggung 
jawab, kemanusiaan, bersifat religiusm membutuhkan perhatian, memiliki kecakapan verbal, hubungan antarpribadi, kegiatan-kegiatan rapi dan teratur, menjauhkan bentuk pemecahan masalah secara intelektual, lebih berorientasi pada perasaan. Contoh pekerjaan orang dengan model orientasi ini adalah, guru, pekerja sosial, konselor, misionari, psikolog klinik, terapis, dan pekerjaan lain yang sejenis.

Dari hasil test hubungan MI dangan test SDS maka dapat dilihat di diagram dibawah ini.

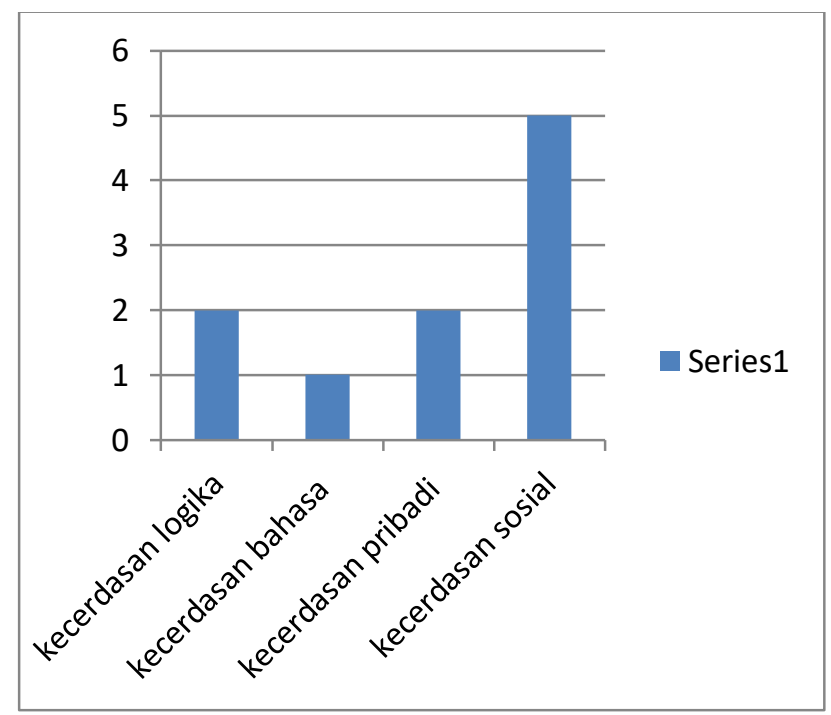

Dari diagram batang diatas dapat dilihat sebaran kecerdasan sosial pada mahasiswa bimbingan dan konseling sangat tinggi. Kemampuan kecerdasaan sosial sangat diperlukan memahami dan berinteraksi dengan orang lain secara efektif. Jenis pekerjaan pada kecerdasan ini sangat relevan dengan output dari lulusan mahasiswa bimbingan dan konseling yaitu sebagai guru BK.

Darihasil test SDS dapat dilihat pada diagram batang dibawah ini.

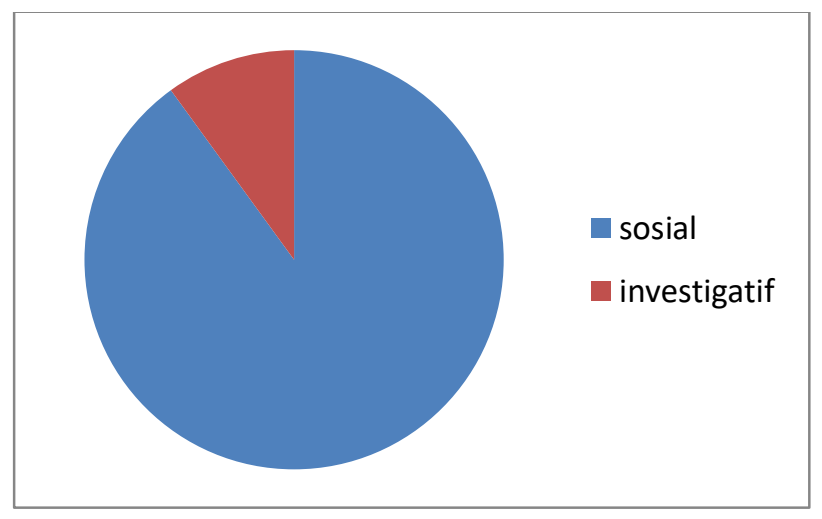

Dari

diagram

lingkarandiatasdapatdilihatsebarankarirmahasiswabimbin gandnakonseling. Tipekepribadiandarihasil test SDS paling tinggipadabidangsosial yang dapatkakansebagaipenunjangpadakecerdasansosial yang dimiliki. Jenispekerjaanutamamenjadi guru BK namunadaalternatifpekerjaan lain yaitu yang berhubungandengankecenderunganuntukmemilihlapanga npekerjaan yang bersifatmembantu orang lain.

\section{PENUTUP}

\section{Simpulan}

Kematangan karir menggunakan test MI sebagai pendukung test SDS pada mahasiswa Universitas Pancasakti Tegal memiliki korelasi yang positif dan saling menunjang. Dari hasil test MI menunjukan kecerdasan sosial yang tinggi sangat diperlukan untuk profesi yang bersifat membantu orang lain. Hal ini dilihat dari hasil test SDS dengan hasil tertinggi dibidang sosial.

\section{Saran}

Bagi mahasiswa, membuat pilihan karir dan keputusan karir merupakan hal yang sangat penting untuk masa depan. Oleh karena itu jangan hanya fokus pada penyelesaian skripsi tetapi juga harus sudah memikirkan karir untuk masa depan.

Bagi peneliti lain, hasil penelitian ini dapat dijadikan acuan dalam penelitian selanjutnya berkaitan dengan kematangan pilihan karir.

\section{DAFTAR PUSTAKA}

Ardimen. 2016. Pengembangan Multiple Intelligence Melalui Pembelajaran Integratif Berbasis Games (Model Integrasi Bimbingan dalam Proses Pembelajaran Sebagai Upaya Mengembangkan Berbagai Potensi Kecerdasan Siswa). Jurnal Edukasi. 2(2): 107-129

Budisiwi, Hastin. 2013. Model Bimbingan Karir Holland Untuk Meningkatkan Kematangan Pilihan Karir Siswa SMK YPT Kota Tegal. Tesis. Semarang: Program Pascasarjana Universitas Negeri Semarang.

Howard, Gardner. 2003. Multiple Intelligence (Kecerdasan Majemuk). Batam: Interaksara http://www.cookps.act.edu.au/mi.htm

Munandir. 1996. Program Bimbingan Karier Di Sekolah. Jakarta: Dikti Depdikbud

Riyadi, A.R. 2006. Pengembangan Alat Ukur Kematangan Karir Siswa Sekolah Menengah Atas. Skripsi pada Jurusan PPB FIP UPI. Bandung : tidak diterbitkan.

Sugiyono. 2009. Memahami Penelitian Kualitatif. Bandung: CV. Alfabeta.

Tigor. 2013. Pengembangan Model Bimbingan Kelompok dengan Teknik Pemecahan Masalah untuk Meningkatkan Kematangan Karir Siswa SMK Negeri 11 Semarang Tahun Pelajaran 2012/2013, 38- 
39.Tesis. Semarang: Program Pascasarjana Universitas Negeri Semarang.

Visser Beth A, Michael C.Ashton \& Philip A.Vernonb. 2006. $G$ And The Measurement Of Multiple Intelligences: A response to Gardner. Elsevier Science Direct. (34) : 507-510

Wijk Charles H. Van, Fauri Marilize. 2017. The Appropriateness of Using the Self-Directed Search Questionnaire in Developing Countries. Open Journal of Social Sciences. (5) : $60-69$ 